Review

\title{
Calcium Silicate Cements vs. Epoxy Resin Based Cements: Narrative Review
}

\author{
Mario Dioguardi *(D), Cristian Quarta (D), Diego Sovereto, Giuseppe Troiano (D), \\ Khrystyna Zhurakivska (D), Maria Eleonora Bizzoca (D), Lorenzo Lo Muzio (D) and Lucio Lo Russo
}

Department of Clinical and Experimental Medicine, University of Foggia, Via Rovelli 50, 71122 Foggia, Italy; cristian_quarta.549474@unifg.it (C.Q.); diego_sovereto.546709@unifg.it (D.S.); giuseppe.troiano@unifg.it (G.T.); khrystyna.zhurakivska@unifg.it (K.Z.); marielebizzoca@gmail.com (M.E.B.); lorenzo.lomuzio@unifg.it (L.L.M.); lucio.lorusso@unifg.it (L.L.R.)

* Correspondence: mario.dioguardi@unifg.it

Received: 22 December 2020; Accepted: 5 February 2021; Published: 8 February 2021

\begin{abstract}
In recent years, calcium silicate cements have been introduced. The purpose of this study is to analyze the main differences between calcium silicate-based cements and epoxy resin-based cements, analyzing the scientific literature of the last year to highlight the main advantages for predictable clinical use. Data collected from the included studies were used in order to analyze different features: chemical-physical properties, cytotoxicity and cell migration, inflammatory response, mineralizing and osteogenic activity, ion release and the filling efficiency of root canals. The calcium silicate cements analyzed in these studies showed good biological and mechanical properties compared to conventional resin-based cements, resulting in better biocompatibility and less cytotoxicity; long-term studies are needed, but these cements have ideal characteristics to allow efficient filling of root canals.
\end{abstract}

Keywords: calcium silicate sealer; root canal sealer; bioceramic cement

\section{Introduction}

Three-dimensional filling of the entire root canal by sealing the passage from the canal to the apex, aims at preventing microorganisms from re-entering into the system [1-5]. Materials used for the filling must be biocompatible and non-resorbable, so that they can act as a dressing in the transition zone between the filling and periapical tissue $[6,7]$.

Cements play an important role in sealing the entire root canal system by excluding the remaining microorganisms from filling the inaccessible areas of the prepared canals. Used in combination with a base material, they have been shown to have an excellent result on the long-term outcome of endodontic treatment [8]. According to Grossman [9], an ideal root cement must guarantee: an excellent seal, good dimensional stability, a slow setting time to ensure adequate working time, insolubility to tissue fluids, adequate adhesion to the root walls and biocompatibility.

AH Plus (Dentsply DeTrey, Konstanz, Germany) is an epoxy resin root canal cement considered the gold standard due to its chemical-physical properties [10]. However, the main limitation of this cement is the absence of bioactive properties [11]. Calcium silicate cements were introduced for the first time in 2007 [12], they were defined as: bioceramic materials, in other words, a subset of materials that can be defined as bio-inert, biocompatible or biodegradable, according to their interactions with surrounding tissue $[13,14]$. Bioactive materials favor the periapical healing process [11]; they also favor higher $\mathrm{pH}$ values and the release of $\mathrm{Ca}^{2+}$ ions and have an adhesion strength similar to that of other cement [10].

The knowledge of the possible different chemical, physical and biological properties existing between two classes of endodontic cements, can be useful for clinicians to address some endodontic 
problems, such as: closure of open apexes [15], perforations of the pulp chamber floor [16], persistent root infections [17] and root resorption [18].

Previous literature reviews did not directly compare these two classes of cements; in fact a recent review conducted by Lim et al. [19] compared these two classes of cements with a focus on the biocompatible properties of calcium silicate cements; previously another systematic review of the literature directly compared these two categories of endodontic cements but focused only on the dislodgment resistance.

The novelty of this review of the literature lies in an exhaustive comparison between the calcium silicate cements and the epoxy resins groups in light of the discoveries made in recent years, taking into careful consideration the aspects of the chemical-physical, cytotoxic, osteogenic, release properties of ions and sealing capacity.

The null hypothesis is that there is no difference in clinical use between the two classes of cement and that both have overlapping characteristics.

The purpose of this work is to analyze the main differences between calcium silicate-based cements and epoxy resin-based cements, in the work of the scientific literature of the last year, to highlight the main advantages for a predictable clinical use.

\section{Materials and Methods}

Articles were identified using electronic databases such as PubMed and Scopus. The electronic research was performed in the period between 1 November 2020 and 25 December 2020 and an additional research was conducted on 27 January 2021, for an update of the results.

Keywords used were: "epoxy resin sealer" and "calcium silicate sealer" for both search providers. The exclusion criteria were as follows:

- $\quad$ Articles not written in English,

- Narrative reviews and systematic reviews,

- Studies that did not focus on physical chemical aspects, biocompatibility and sealing ability,

- Studies that only treated a class of cements, or that only reported data and information for one type of endodontic cement,

- $\quad$ Studies published before 2010.

At the end of the selection process, the following 13 studies were selected for qualitative analysis: Zordan-Bronzel et al. (2019) [20], Chen et al. (2020) [21], Torres et al. (2020) [22], Seo et al. (2019) [23], Lee et al. (2019) [24], López-García et al. (2020) [25], Gaudin et al. (2020) [26], Sanz et al. (2020) [27], Rodríguez-Lozano et al. (2020) [28], Alves Silva et al. (2020) [29], Kim et al. (2019) [30], Milanovic et al. (2020) [31] and Kim et al. (2020) [32] (Figure 1). 


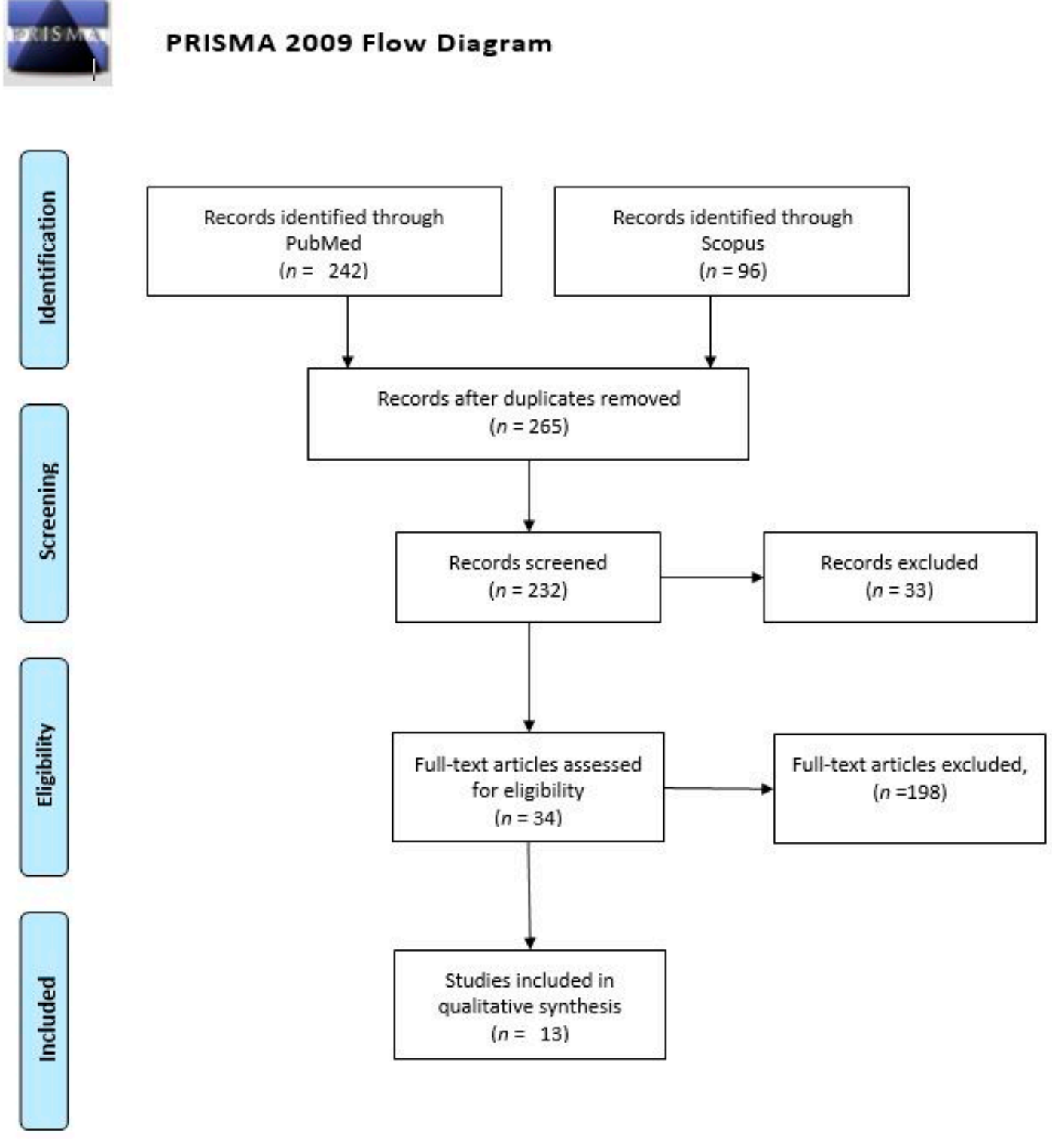

Figure 1. Flowchart of the different phases of the review. Identification: 338; screening: 19; eligibility 34 and included: 13.

\section{Results}

Data extracted from the included studies (Tables 1 and 2) allowed analyzing and discussing of the following points:

i. Chemical-physical properties

ii. Cytotoxicity and cell migration

iii. Inflammatory response

iv. Mineralizing and osteogenic activity

v. Ion release

vi. Filling efficiency of root canals 
Table 1. Materials and features covered in each study.

\begin{tabular}{|c|c|c|}
\hline Author, Date, Journal & Materials & Features Analyzed \\
\hline $\begin{array}{l}\text { Zordan-Bronzel, 2019, Journal of } \\
\text { endodontics [20] }\end{array}$ & $\begin{array}{c}\text { Bio-C Sealer, TotalFill BC Sealer, AH } \\
\text { Plus }\end{array}$ & chemical-physical properties \\
\hline $\begin{array}{l}\text { Chen, 2020, Journal of } \\
\text { endodontics [21] }\end{array}$ & $\begin{array}{c}\text { EndoSequence BC Sealer, } \\
\text { EndoSequence BC Sealer HiFlow }\end{array}$ & $\begin{array}{l}\text { chemical-physical properties, } \\
\text { cytotoxicity }\end{array}$ \\
\hline $\begin{array}{l}\text { Torres, 2020, International } \\
\text { endodontic journal [22] }\end{array}$ & $\begin{array}{c}\text { Total Fill BC, Sealer Plus BC, Bio-C } \\
\text { Sealer, AH Plus }\end{array}$ & chemical-physical properties \\
\hline Seo, 2019, Materials [23] & $\begin{array}{c}\text { EndoSequence BC Sealer, BioRoot RCS, } \\
\text { Endoseal MTA, AH Plus }\end{array}$ & $\begin{array}{l}\text { cytotoxicity and cell migration, } \\
\text { mineralizing and osteogenic activity }\end{array}$ \\
\hline Lee, 2019, Materials [24] & $\begin{array}{c}\text { EndoSeal MTA, Nano-ceramic Sealer, } \\
\text { Wellroot ST, AH Plus, AD Seal }\end{array}$ & $\begin{array}{l}\text { cytotoxicity and cell migration, } \\
\text { inflammatory response }\end{array}$ \\
\hline $\begin{array}{l}\text { López-García, 2020, Clinical oral } \\
\text { investigations [25] }\end{array}$ & $\begin{array}{c}\text { EndoSequence BC Sealer, Ceraseal, } \\
\text { Endoseal MTA }\end{array}$ & $\begin{array}{l}\text { cytotoxicity and cell migration, } \\
\text { mineralizing and osteogenic activity, } \\
\text { ion release }\end{array}$ \\
\hline $\begin{array}{l}\text { Gaudin, 2020, Journal of } \\
\text { endodontics [26] }\end{array}$ & $\begin{array}{c}\text { BioRoot RCS, ProRoot ES, MTA Fillapex, } \\
\text { AH Plus }\end{array}$ & $\begin{array}{l}\text { cytotoxicity and cell migration, } \\
\text { inflammatory response }\end{array}$ \\
\hline $\begin{array}{l}\text { Sanz, 2020, Clinical oral } \\
\text { investigations [27] }\end{array}$ & $\begin{array}{c}\text { Bio-C Sealer ION+, EndoSequence BC } \\
\text { Sealer HiFlow, AH Plus }\end{array}$ & $\begin{array}{l}\text { cytotoxicity and cell migration, } \\
\text { mineralizing and osteogenic activity, } \\
\text { ion release }\end{array}$ \\
\hline $\begin{array}{c}\text { Rodríguez-Lozano, 2020, } \\
\text { International endodontic } \\
\text { journal [28] }\end{array}$ & $\begin{array}{l}\text { EndoSequence BC Sealer HiFlow, } \\
\text { EndoSequence BC Sealer, AH Plus }\end{array}$ & $\begin{array}{l}\text { cytotoxicity and cell migration, } \\
\text { mineralizing and osteogenic activity }\end{array}$ \\
\hline $\begin{array}{c}\text { Alves Silva, 2020, Journal of } \\
\text { endodontics [29] }\end{array}$ & Bio-C Sealer, Sealer Plus BC, AH Plus & $\begin{array}{c}\text { inflammatory response, mineralizing } \\
\text { and osteogenic activity }\end{array}$ \\
\hline $\begin{array}{c}\text { Kim, 2019, Restorative dentistry \& } \\
\text { endodontics [30] }\end{array}$ & EndoSeal MTA, AH Plus & Root canal filling efficiency \\
\hline $\begin{array}{l}\text { Milanovic, 2020, Journal of } \\
\text { endodontics [31] }\end{array}$ & $\begin{array}{c}\text { BioRoot RCS, EndoSequence BC Sealer, } \\
\text { MTA Fillapex, AH Plus }\end{array}$ & Root canal filling efficiency \\
\hline $\begin{array}{c}\text { Kim, 2020, Restorative dentistry \& } \\
\text { endodontics [32] }\end{array}$ & Endoseal MTA, AH Plus & Root canal filling efficiency \\
\hline
\end{tabular}

Table 2. Shows the main cements used in the various studies with the relative compositions.

\begin{tabular}{|c|c|c|}
\hline Material & Manufacturer & Composition \\
\hline AH Plus & $\begin{array}{l}\text { Dentsply DeTrey GmbH, } \\
\text { Konstanz, Germany }\end{array}$ & $\begin{array}{l}\text { Bisphenol-A epoxy resin, bisphenol-F epoxy resin, calcium } \\
\text { tungstate, zirconium oxide, silica, iron oxide pigments } \\
\text { dibenzyldiamine, aminoadamantane, silicone oil }\end{array}$ \\
\hline AD Seal & $\begin{array}{l}\text { MetaBiomed, } \\
\text { Cheongju, Korea }\end{array}$ & $\begin{array}{c}\text { Base: }<20 \% \text { epoxy resin, NS calcium phosphate, } \\
\text { NS zirconium dioxide, NS calcium oxide, } \\
\text { NS ethylene glycol, salicylate } \\
\text { Catalyst: } 2.5-10 \% \text { N, n-dibenzyl-5-oxanonandiamin- } 1,9, \\
2.5-10 \% \text { amantadine }\end{array}$ \\
\hline TotalFill BC & $\begin{array}{c}\text { FKG Dentaire SA, La } \\
\text { Chaux-de-Fonds, Switzerland }\end{array}$ & $\begin{array}{c}\text { Zirconium oxide, calcium silicates, calcium phosphate } \\
\text { monobasic, calcium hydroxide, filler } \\
\text { and thickening agents }\end{array}$ \\
\hline Bio-C Sealer & Angelus, Londrina, PR, Brazil & $\begin{array}{c}\text { Calcium silicates, calcium aluminate, calcium oxide, } \\
\text { zirconium oxide, iron oxide, silicon dioxide, } \\
\text { dispersing agent }\end{array}$ \\
\hline $\begin{array}{l}\text { EndoSequence BC } \\
\text { Sealer }\end{array}$ & Brasseler, Savannah, GA, USA & $\begin{array}{c}\text { Zirconium oxide, calcium silicates, calcium phosphate } \\
\text { monobasic, calcium hydroxide, filler } \\
\text { and thickening agents }\end{array}$ \\
\hline $\begin{array}{l}\text { EndoSequence BC } \\
\text { Sealer HiFlow }\end{array}$ & $\begin{array}{l}\text { Brasseler, Savannah, } \\
\text { GA, USA }\end{array}$ & $\begin{array}{l}\text { Zirconium oxide, tricalcium silicate, dicalcium silicate, } \\
\text { calcium hydroxide, fillers }\end{array}$ \\
\hline Sealer Plus BC & MK Life, Porto Alegre, RS, Brazil & $\begin{array}{l}\text { Zirconium oxide, tricalcium silicate, dicalcium silicate, } \\
\text { calcium hydroxide and propylene glycol }\end{array}$ \\
\hline BioRoot RCS & $\begin{array}{l}\text { Septodont, Saint } \\
\text { Maur-des-Fossés, France }\end{array}$ & $\begin{array}{l}\text { Tricalcium silicate, zirconium oxide (opacifier) } \\
\text { and excipients in its powder form, and calcium } \\
\text { chloride and excipients as an aqueous liquid }\end{array}$ \\
\hline Endoseal MTA & $\begin{array}{l}\text { Maruchi, Wonju, } \\
\text { Korea }\end{array}$ & $\begin{array}{c}\text { Calcium silicates, calcium aluminates, calcium } \\
\text { aluminoferrite, calcium sulfates, radiopacifier, } \\
\text { and thickening agents }\end{array}$ \\
\hline
\end{tabular}


Table 2. Cont

\begin{tabular}{|c|c|c|}
\hline Material & Manufacturer & Composition \\
\hline Nano-ceramic Sealer & B\&L Biotech, Fairfax, VA, USA & $\begin{array}{c}\text { Calcium silicates, zirconium oxide, filler, thickening agent } \\
\text { Calcium silicate compound, calcium sulfate dehydrate, } \\
\text { calcium sodium phosphosilicate, zirconium } \\
\text { oxide, titanium } \\
\text { oxide, thickening agents }\end{array}$ \\
\hline Ceraseal & $\begin{array}{c}\text { Meta Biomed Co., 270, } \\
\text { Osongsaengmyeong } \\
\text { 1-ro, Osong-eup, Heungdeok-gu, } \\
\text { Cheongju-si, } \\
\text { Chungcheongbuk-do, South Korea }\end{array}$ & Calcium silicates, zirconium oxide, thickening agent \\
\hline ProRoot ES & Dentsply Sirona, York, PA & $\begin{array}{c}\text { Powder: calcium sulphate, dicalcium silicate, tricalcium } \\
\text { silicate, bismuth oxide, and a bit of tricalcium aluminate } \\
\text { Liquid (viscous aqueous solution of a } \\
\text { water-soluble polymer) }\end{array}$ \\
\hline MTA Fillapex & Angelus, Londrina, PR, Brazil & $\begin{array}{c}\text { Paste A: salicylate resin, bismuth trioxide, and fumed silica } \\
\text { Paste B: fumed silica, titanium dioxide, mineral trioxide } \\
\text { aggregate, and base resin }\end{array}$ \\
\hline Bio-C Sealer ION ${ }^{+}$ & $\begin{array}{c}\text { Angelus, Londrina, } \\
\text { PR, Brazil }\end{array}$ & $\begin{array}{c}\text { Calcium silicate, magnesium silicate, polyethylene glycol, } \\
\text { zirconium oxide, silicon dioxide nanoparticles, } \\
\text { potassium sulphate, calcium sulphate hemihydrate }\end{array}$ \\
\hline
\end{tabular}

\section{Discussion}

\subsection{Chemical-Physical Properties}

Three studies evaluated the chemical-physical properties of the endodontic cements.

The setting time of endodontic cements should ensure the possibility of inserting the material inside the root canals before it hardens [33]; however, excessive setting time is considered a critical problem in the clinical context of the placement [34]. In the study by Zordan-Bronzel et al. (2019), Bio-C Sealer had the shortest setting time followed by AH Plus and TotalFill BC Sealer [20], which had the longest setting time. In the study of Chen et al. (2020) [21], EndoSequence BC Sealer HiFlow and EndoSequence BC Sealer, when subjected to $100{ }^{\circ} \mathrm{C}$ for $1 \mathrm{~min}$, did not change in the initial and final setting times.

Flow is an important property of cements and allows them to penetrate irregularities in the root canal system [35]; however, solubility indicates the mass loss of the material if immersed in water [33]; endodontic cements should exhibit solubility of less than 3\% (American National Standards, 2000) in order to maintain their sealing ability and avoid reinfection [12]. In the Zordan-Bronzel et al. study [20], Bio-C Sealer had higher flow and solubility values than the other two cements; the low solubility of AH Plus can be attributed to the strong cross bonds that form in the epoxy resin-based materials [36], while the high solubility of calcium silicate cements can be explained by the presence of hydrophilic nanometric particles that increase their surface and allow greater contact of liquid molecules with the cement [37].

In the Torres et al. study, after immersion in distilled water, all calcium silicate-based cements had high solubility values [22]. The values after immersion in phosphate-buffered saline were significantly lower compared to immersion in water, in any case the values were higher than the minimum required according to ISO 6876. Bio-C had significantly greater solubility, followed by TotalFill BC and Sealer Plus AC, which had similar values. AH Plus had the lowest solubility in distilled water and in phospate-buffered saline, with similar values for both solutions and compliant with ISO standards [22].

The calcium silicate cements in the study by Chen et al. [21], subjected to $100{ }^{\circ} \mathrm{C}$ for $1 \mathrm{~min}$, underwent a decrease in the flow but always in accordance with ISO 6876/2001 recommendations; EndoSequence BC Sealer HiFlow had a greater flow than EndoSequence BC Sealer both at room temperature and at $100^{\circ} \mathrm{C}$.

The radio-opacity of endodontic cements is essential for the assessment of the filling and for the distinction of the material from the surrounding anatomical structures [38]; in the study of 
Zordan-Bronzel et al. [20], AH Plus showed the highest radio-opacity and the lowest solubility and volumetric variation, while Bio-C Sealer and TotalFill BC Sealer had a similar volumetric change and similar radio-opacity; in the study of Chen et al. there was a significant increase in the thickness of the EndoSequence BC Sealer film at $100{ }^{\circ} \mathrm{C}$ for $1 \mathrm{~min}$, while the thickness of the EndoSequence BC Sealer HiFlow film was not influenced by temperature and was much lower than BC Sealer. HiFlow had significantly higher radio-opacity than BC Sealer. In general, EndoSequence BC Sealer HiFlow has shown better results in terms of flow, viscosity and thickness of the film, in particular at the high temperatures that are generated during the hot compaction technique [21,37].

In the Torres et al. study, AH Plus had the lowest volumetric variation, regardless of the immersion liquid. In addition, AH Plus was the only material that had a volume gain, with similar values for distilled water and phospate-buffered saline. TotalFill BC, Sealer Plus BC and Bio-C were similar and had significantly greater volume loss when immersed in distilled water [22].

An alkaline environment can play a positive role in apical healing, thus contributing to the formation of mineralized tissues [39]; in the Zordan-Bronzel et al. study, the $\mathrm{pH}$, after $1 \mathrm{~d}$, was higher for TotalFill BC Sealer followed by Bio-C Sealer and AH Plus, which had values more similar to those of the control; no statistically significant difference was observed between TotalFill BC Sealer and Bio-C Sealant in the other experimental time-points [20].

\subsection{Cytotoxicity and Cell Migration}

Cytotoxicity and cell migration have been analyzed in seven different studies, generally with the use of the methyl-thiazoldiphenyltetrazolium (MTT) assay for the study of cytotoxicity and with the wound healing assay for the study of cell migration [2-4].

Endodontic cement can extrude into the periapical tissue during its injection, this means that cement can contact cells in the periodontal ligament space directly due to its fluidity, which can cause acute inflammation in the periapical area $[40,41]$.

Cell viability is defined as the percentage of live cells in an entire population and the toxicity of materials is usually analyzed [42].

In the study by Seo et al., three calcium silicate cements (EndoSequence BC Sealer, BioRoot RCS, Endoseal MTA) and an epoxy resin-based cement (AH Plus) were assessed, together with a control, on stem cells taken from the dental pulp and cultured in single layer; in the first $48 \mathrm{~h}$ there were no statistically significant differences in cell viability between the various study groups, while after $72 \mathrm{~h}$ the group tested with AH Plus showed the lowest cell viability; in cell migration, BioRoot RCS showed slower migration than the other two calcium silicate cements for up to $72 \mathrm{~h}$, while at $96 \mathrm{~h}$ it showed similar wound healing rates; however, no wound healing was observed in the AH Plus group with statistically significant differences at 48,72 and $96 \mathrm{~h}$ [42].

In the study of Lee et al., three calcium silicate cements (EndoSeal MTA, Nano-ceramic Sealer, and Wellroot ST) were compared with two epoxy resin-based cements (AH Plus, AD Seal) tested on stem cells taken from the periodontal ligament; cell viability was lower in the AH Plus group in all observation periods; the viability of the groups with AHPlus, Wellroot ST and EndoSeal MTA has significantly decreased over time; in the 48-h extraction medium there were no significant differences between the various samples tested, and in the 72-h extraction medium the cell viability with Wellroot ST was the highest while that of Nano-ceramic Sealer decreased significantly after $7 \mathrm{~d}$ [24].

In the study of Chen et al. the cell viability of periodontal ligament fibroblast cultures was assessed by Cell Counting Kit-8; the cultures were incubated with two calcium silicate cements: EndoSequence BC Sealer and EndoSequence BC Sealer HiFlow; no significant differences were recorded between the two incubations; for both cements. In particular, fibroblasts incubated in 1:4 diluted extract for $3 \mathrm{~d}$ had significantly lower cell viability than other incubation times and other extract concentrations. When the concentration of the cement extract was diluted to 1:8 or less, no effect on the viability of the fibroblasts was detected at any time of exposure [21]. 
López-García et al. evaluated the cytocompatibility of three calcium silicate cements: EndoSequence BC Sealer, Ceraseal and Endoseal MTA on stem cell cultures taken from the periodontal ligament. The sealants Ceraseal and EndoSequence BC showed similar viability rates compared to control (MTT assay) with increased viability at $72 \mathrm{~h}$, while Endoseal showed decreased cell viability [42]. In addition, the wound healing results indicate that the migration has progressed in all experimental conditions, with the exception of the pronounced deceleration of migration in incubation with Endoseal; it is interesting to note that treatments involving the 1:1 and 1:2 dilutions of EndoSequence BC Sealer induced a higher cell migration rate at $72 \mathrm{~h}$ compared to the complete control medium, this could be due to the change in viscoelasticity in the media and to the mechanical coupling between cells influencing migration as mentioned in a recent study [43].

Gaudin et al. evaluated the effects of various calcium silicate cements (BioRoot RCS, ProRoot ES and MTA Fillapex) and AH Plus on the vitality of stem cells of the periodontal ligament; the increase in the viability of cells cultured with BioRoot RCS was statistically significant in all dilutions; ProRoot ES had no effect on cell viability regardless of dilution [26]; MTA Fillapex was highly cytotoxic even at the lowest extract dilutions; on the other hand, AH Plus showed mild toxicity with a high concentration of extract. In 3D encapsulation of cells with $0.25 \%$ PuraMatrix, BioRoot RCS and ProRoot ES they showed an increase in cell viability at the lowest dilutions, and remain non-cytotoxic in other concentrations. MTA Fillapex remained cytotoxic at high extract concentrations, while with 1:2 dilutions or further dilutions it is not cytotoxic; there were no significant differences in the viability of the cells exposed to extracts from AH Plus. In an experimental in vitro root model procedure, BioRoot RCS, ProRoot ES, MTA Fillapex and AH Plus had no toxic effects on cell viability, with MTT results very similar to the negative control group.

Sanz et al. tested the cytocompatibility and cell migration of two calcium silicate cements (Bio-C Sealer $\mathrm{ION}^{+}$and EndoSequence BC Sealer HiFlow) and AH Plus on periodontal ligament stem cells; the first two cements showed good biocompatibility without significant differences, unlike AH Plus, whose production was significantly lower. With regard to migration, a significant migration was found in the group tested with $\mathrm{ION}^{+}$in the 1:4 group diluted to $48 \mathrm{~h}$ compared to the control group, while no significant difference was observed at 24 or $72 \mathrm{~h}$ in any dilution. At $24 \mathrm{~h}$, significant differences were observed in all dilutions of $\mathrm{BCHiF}$ compared to the control group, while at $48 \mathrm{~h}$, significant differences were observed only in the undiluted extracts. As for the AH Plus group, in all time periods and dilutions, the cell migration rate was significantly lower than that of the control group [26].

Rodríguez-Lozano et al. evaluated the viability and cell migration of EndoSequence BC Sealer HiFlow, EndoSequence BC Sealer and AH Plus on periodontal ligament stem cells; the undiluted extracts of HiFlow and BC Sealer increased the viability rates significantly compared to the levels of the 24-h control group while with the AHP group at the same time the cell viability rates decreased; at 48 and $72 \mathrm{~h}$, neither group of calcium silicate cements underwent significant changes in viability rates compared to the control group, while in the AHP group there were decreases in the proliferation rat [28].

In all periods and dilutions studied, cell migration rates in the EndoSequence BC Sealer group were similar to those in the control group and no detectable differences were found. In the HiFlow group, only at $24 \mathrm{~h}$ in the undiluted group, were significant differences detected, while no significant differences were detected at 48 or $72 \mathrm{~h}$ in any dilution with respect to wound closure of the control group. On the contrary, in all periods and all dilutions, the AH Plus group showed significant differences, not being able to migrate compared to the control group.

\subsection{Inflammatory Response}

Three studies evaluated the cellular inflammatory response induced by endodontic cements.

Proinflammatory cytokines are involved in the upregulation of inflammatory reactions. Some pro-inflammatory cytokines, such as IL-1 $\beta$ (interleukin-1 $\beta$ ), IL-6 and TNF- $\alpha$ (tumor necrosis factor- $\alpha$ ) are involved in the pathological pain process [44]. IL-6 is a pleiotropic cytokine that 
acts as the main mediator in the host response after a tissue injury, with a stimulating effect on bone osteoclasts and autocrine/paracrine bone resorption [45]. IL-8 and GRO (growth-regulated oncogene) are chemokines that mediate different functions, such as attracting neutrophils to sites of inflammation and regulation of angiogenesis. Therefore, it could be hypothesized that up-regulation of such proinflammatory cytokines and chemokines may be associated with inflammatory response, periapical lesions, increased osteoclastogenesis and bone resorption in cases of extrusion of root filling materials [26].

Lee et al., for the evaluation of the inflammatory response induced by the three-calcium silicate and two epoxy resin-based cements, used an enzyme-linked immunosorbent assay (ELISA); AH Plus exhibited a significantly higher expression of IL-6 and IL-8 than other cements [24].

Alves Silva et al. evaluated the inflammatory response of Bio-C Sealer, Sealer Plus BC (calcium silicate cements) and AH Plus (based on epoxy resin) in rat subcutaneous tissues, through the evaluation of the density of inflammatory cells, using a light microscope and image analysis system; they also assessed the presence of IL-6 through an ELISA [29]; at 7 days, Sealer Plus BC showed lower inflammatory cell values than Bio-C Sealer; after 15 days Bio-C showed fewer inflammatory cells and IL-6 than other materials; after 60 days the calcium silicate cements did not show statistically significant differences for inflammatory cells and IL-6, with lower values compared to AH Plus.

Gaudin et al. evaluated the effect of some calcium silicate cements on the production of cytokines via EMD Millipore [26]; no significant differences between BioRoot RCS, ProRoot ES and the negative control were observed for IL-6 and IL-8; however, unlike BioRoot RCS, ProRoot ES caused a significant decrease in the production of growth-regulated oncogene (GRO). Both MTA Fillapex and AH also caused significant up-regulation of IL-6, IL-8 and GRO in the culture medium compared to the negative control group. BioRoot RCS greatly stimulated the release of IL-10 and, to a lesser extent, IL-4 compared to the negative control group. ProRoot ES and MTA Fillapex showed a slight increase in IL-10 production, while AH Plus had no effect on IL-10 production; IL-10 is an inflammatory cytokine that inhibits the production of proinflammatory cytokines including IL- $1 \mathrm{~b}$, IL-6 and alpha tumor necrosis factor. IL-4 is another anti-inflammatory cytokine that plays a role in the formation of Th2 lymphocytes and in moving the macrophage phenotype into cells that produce IL-10 that would be compatible with healing macrophages (M2) [46].

Based on these data, AH Plus has the lowest cytocompatibility compared to calcium silicate cements, potentially triggering an innate inflammatory response.

\subsection{Mineralizing and Osteogenic Activity}

Calcium silicate cements have several favorable properties, including the ability to induce formation of hard tissues and biocompatibility; they are also non-toxic, non-resorbable and not influenced by blood contamination, also being able to induce the proliferation of undifferentiated cells (human mesenchymal stem cells) and support their adhesion, proliferation and migration [47-49]. These properties, as widely described by Singh et al., depend fundamentally on the structural rigidity of these materials and on their inertia which avoids inflammation and consequent displacement of the cement with respect to the surrounding tissue, favoring osseointegration [49]. Six studies analyze the mineralizing and osteogenic activity of such classes of endodontic cements.

Seo et al. evaluated the mineralizing activity of three calcium silicate cements (EndoSequence BC Sealer, BioRoot RCS, Endoseal MTA) and an epoxy resin-based cement (AH Plus) through Alizarin Red staining assay; cells in contact with calcium silicate cements showed a significant increase in the formation of calcium nodules compared to the group tested with AH Plus at 15 days [23].

Lee et al. evaluated the osteogenic activity of three calcium silicate cements (EndoSeal MTA, Nano-ceramic Sealer, and Wellroot ST) with two epoxy resin-based cements (AH Plus, AD Seal) using RT-qPCR (real time polymerase chain reaction) and alkaline phosphatase staining; RUNX2 (runt-related transcription factor 2) mRNA expression showed no significant difference between the materials; however, the expression of alkaline phosphatase mRNA, and its staining, showed a 
significant time-related increase on all three calcium silicate-based cements [24]. RUNX2 is a key transcription factor associated with osteoblast differentiation; regulates osteogenic genes, in relation to the beginning and end of the cell cycle of osteoblasts, and plays a role in regulating cell proliferation [50].

López-García et al. assessed the expression of genes such as ALP (alkaline phosphatase), osteogenesis marker, and CEMP-1 (cementum protein-1) and CAP (cementum attachment protein) for cementogenesis, using RT-qPCR; the mineralizing activity was assessed through Alizarin Red staining assay; Ceraseal and EndoSequence induced the expression of ALP, CAP, CEMP-1 and showed a significantly higher mineralizing capacity than Endoseal [25].

The expression of ALP, CAP and CEMP-1 is related to the formation of cement and bone tissue and has previously been reported in promoting either in vitro osteoblastic, cementoblastic, or both, differentiation of stem cells of the periodontal ligament; regulate cell viability, differentiation, deposition rate, composition and morphology of the hydroxyapatite crystals formed by these cells [28].

Sanz et al. used RT-qPCR to evaluate the gene expression of CAP, CEMP-1, ALP and RUNX2, and Alizarin Red staining assay to determine the mineralization potential of cells; the HiFlow tested group showed an up-regulation of CAP, CEMP-1, ALP and RUNX-2, compared to the negative control, while Bio-C Sealer ION ${ }^{+}$showed an up-regulation of CEMP-1, CAP and RUNX2; both groups also showed greater mineralization potential than negative and positive controls. For the AHP group, RT-qPCR analysis was not performed due to cell death shown by previous cytocompatibility tests [27].

Rodríguez-Lozano et al. assessed the gene expression of ALP, CEMP-1 and CAP through RT-qPCR, and the mineralizing activity through Alizarin Red Staining Assay; on day 7, the expression of ALP, CEMP-1 and RUX2 was significantly higher in the EndoSequence BC Sealer and HiFlow groups; since AHP resulted in cell death, the qPCR analysis in this group was not analyzed. The mineralization capacity of the tested materials was detected by the Alizarin Red coloring; the Bioceramic groups produced significantly more calcium deposits than the control only after 21 days of culture. The greatest mineralization capacity was observed in the group tested with EndoSequence BC Sealer HiFlow; on the other hand, there were no calcium deposits detected in the group with AH Plus, with rates significantly lower than that of the control group [28].

In the study by Alves Silva et al., osteogenic differentiation was assessed with the presence of osteocalcin, a marker of mature osteoblasts, while incubating sections of rat tissue with rabbit anti-osteocalcin antibodies; as early as 7 days, only the Bio-C group showed positive signs for osteocalcin. At 15 and 30 days, Bio-C and Sealer Plus BC had immunopositive cells. After a 60-day period, Bio-C showed more labeled cells than Sealer Plus BC. The AH Plus cement and the control group showed no positive signs in any period [29].

\subsection{Ion Release}

Two studies analyzed the release of ions from calcium silicate cements, by means of coupled plasma mass spectrometry.

Bioactive cements have the ability to release ions and neutralize acids, thus promoting tissue healing; furthermore, it is known that $\mathrm{Ca}^{2+}$ is actively involved in the differentiation of mesenchymal stem cells and in tissue mineralization [51,52].

López-García et al. evaluated the release of ions by calcium silicate cements, through the presence of aluminum, silicon, sulfur, calcium and zirconium; the release of $\mathrm{Ca}^{2+}$ was higher in the case of Ceraseal than in EndoSequence BC Sealer and Endoseal. However, the release of Zr was most pronounced in Ceraseal. Furthermore, the presence of only aluminum is detected in Endoseal [25].

Sanz et al. evaluated the release of calcium, iron, zirconium, silicon and tungsten ions; HiFlow exhibited a significantly higher concentration of $\mathrm{Zr}$ release; both calcium silicate cements showed a higher Ca release than AH Plus cement; Bio-C Sealer $\mathrm{ION}^{+}$released a significantly higher amount of Si than other cements, while the highest tungsten release concentration was detected in AH Plus [27]. 


\subsection{Root Canal Filling Efficiency}

Three studies evaluated the filling efficiency, which is mainly indicated by the presence of voids or pores in the three-dimensional filling space.

Kim et al. (2019) evaluated the obturation efficiency of the root canals by comparing the continuous wave condensation technique (using AH Plus) with the single cone technique (using EndoSeal MTA), on endodontically treated teeth of patients with either irreversible pulpitis, apical periodontitis, or both; the single cone technique showed less filling time, while the number of voids trapped during the canal filling process showed no significant differences between the two techniques [30].

Kim et al. (2020) assessed the quality of root canal filling over time of both extracted human teeth and artificial canals using a calcium silicate cement (Endoseal MTA) with the single cone technique in comparison with canals filled with AH Plus cement. Micro-CT (micro-computed tomography) scans performed immediately after filling the canal did not show significant differences in the percentage of vacuum at all levels between the Endoseal MTA and AH Plus groups in the simulated root canals; after four weeks there were no statistically significant differences in any third of the canals, with the exception of the apical third of the group tested with AH plus which showed a greater percentage of voids; although immediately after filling the canals, Endoseal MTA showed a lower percentage of voids compared to AH plus, over time there seems to be no significant differences between the two [32].

The vacuum does not always cause a treatment failure but can act as a microbial reservoir, therefore it should be minimized as far as possible; the vacuum in the filling materials with the single cone technique could derive from the inconsistent application of the premixed cement during the application procedure, while in the continuous wave technique the vacuum could be trapped between two phases of the filling procedures and inside the backfilling material [30].

Unfilled spaces, particularly open pores, can lead to the regrowth of microorganisms or allow their penetration into the micro-leakage [53]. Closed pores can be considered isolated gaps with much less potential for bacterial growth and migration. This was the logic of the porosity division between open and closed. This approach seems clinically relevant in light of the different potential contributions of open and closed pores to apical periodontitis.

EndoSequence BC Sealer HiFlow has shown good results in terms of flow, viscosity and thickness of the film, in particular at temperatures which are generally generated during the technique of vertical compaction of hot gutta-percha [54].

Milanovic et al. wanted to quantify and compare the closed and open porosity of calcium silicate-based cements (BioRoot RCS, EndoSequence BC Sealer, MTA Fillapex) with epoxy resin-based cements (AH plus), and evaluate the long-term effect of conservation within simulated body fluids on porosity; higher percentages of open porosity than closed porosity were recorded in all samples [31]. Significantly higher open and total porosities were initially found in MTA Fillapex than AH Plus. After six months, the percentage of open and total porosity increased in BioRoot RCS and MTA Fillapex and decreased in AH Plus and EndoSequence BC. Both initially and after storage, the coronal region of all cements had significantly greater total porosity than the middle and apical regions, which were comparable.

\section{Conclusions}

The calcium silicate sealers analyzed in these studies showed good biological and mechanical properties compared to conventional resin-based cements, resulting in being more biocompatible and less cytotoxic; although almost all these types of cements give good results with cold sealing techniques.

In general, calcium silicate-based cements have shown a high release of calcium ions, adequate cytocompatibility, upregulation of osteo-cementogenic genes and an increase in the formation of mineralizing nuclei in contact with the stem cells examined in the various studies. Longer-term studies are needed, but preliminary findings have shown that these sealers have ideal characteristics for efficient filling of root canals. 
Author Contributions: Conceptualization, M.D. and C.Q.; methodology, D.S. and C.Q.; investigation, G.T., K.Z., M.E.B. and L.L.R.; data curation, L.L.M. and L.L.R.; writing-original draft preparation, C.Q., M.E.B., D.S. and M.D.; writing—review and editing, L.L.M., G.T. and L.L.R.; visualization, K.Z. and L.L.M.; supervision, L.L.R. All authors have read and agreed to the published version of the manuscript.

Funding: This research received no external funding.

Conflicts of Interest: The authors declare no conflict of interest.

\section{References}

1. Li, G.-H.; Niu, L.-N.; Zhang, W.; Olsen, M.; De-Deus, G.; Eid, A.A.; Chen, J.-H.; Pashley, D.H.; Tay, F.R. Ability of new obturation materials to improve the seal of the root canal system: A review. Acta Biomater. 2014, 10, 1050-1063. [CrossRef]

2. Buonavoglia, A.; Lauritano, D.; Perrone, D.; Ardito, F.; Troiano, G.; Dioguardi, M.; Candotto, V.; Silvestre, F.J.; Muzio, L.L. Evaluation of chemical-physical properties and cytocompatibility of TheraCal LC. J. Boil. Regul. Homeost. Agents 2017, 31, 1-9.

3. Troiano, G.; Perrone, D.; Dioguardi, M.; Buonavoglia, A.; Ardito, F.; Muzio, L.L. In vitro evaluation of the cytotoxic activity of three epoxy resin-based endodontic sealers. Dent. Mater. J. 2018, 37, 374-378. [CrossRef] [PubMed]

4. Dioguardi, M.; Perrone, D.; Troiano, G.; Laino, L.; Ardito, F.; Lauritano, F.; Cicciù, M.; Muzio, L.L. Cytotoxicity evaluation of five different dual-cured resin cements used for fiber posts cementation. Int. J. Clin. Exp. Med. 2015, 8, 9327-9333. [PubMed]

5. Friedman, S.; Torneck, C.D.; Komorowski, R.; Ouzounian, Z.; Syrtash, P.; Kaufman, A. In vivo model for assessing the functional efficacy of endodontic filling materials and techniques. J. Endod. 1997, 23, 557-561. [CrossRef]

6. Arthanari, K.K.; Palanivelu, C.R.; Ravi, V.; Sivakumar, A.A.; Sivakumar, J.S.; Prasad, A.S. An in vitro comparative evaluation of distribution of three different sealers by single-cone obturation technique. J. Pharm. Bioallied Sci. 2019, 11, S438-S441. [CrossRef]

7. Restrepo-Restrepo, F.A.; Cañas-Jiménez, S.J.; Romero-Albarracín, R.D.; Villa-Machado, P.A.; Pérez-Cano, M.I.; Tobón-Arroyave, S. Prognosis of root canal treatment in teeth with preoperative apical periodontitis: A study with cone-beam computed tomography and digital periapical radiography. Int. Endod. J. 2019, 52, 1533-1546. [CrossRef]

8. Orstavik, D.; Kerekes, K.; Eriksen, H.M. Clinical performance of three endodontic sealers. Dent. Traumatol. 1987, 3, 178-186. [CrossRef] [PubMed]

9. Grossman, L.I. Prevention in Endodontic Practice. J. Am. Dent. Assoc. 1971, 82, 395-396. [CrossRef]

10. Almeida, L.H.S.; Moraes, R.R.; Morgental, R.D.; Pappen, F.G. Are Premixed Calcium Silicate-based Endodontic Sealers Comparable to Conventional Materials? A Systematic Review of In Vitro Studies. J. Endod. 2017, 43, 527-535. [CrossRef]

11. Giacomino, C.M.; Wealleans, J.A.; Kuhn, N.; Diogenes, A. Comparative Biocompatibility and Osteogenic Potential of Two Bioceramic Sealers. J. Endod. 2019, 45, 51-56. [CrossRef]

12. Donnermeyer, D.; Bürklein, S.; Dammaschke, T.; Schäfer, E. Endodontic sealers based on calcium silicates: A systematic review. Odontology 2019, 107, 421-436. [CrossRef] [PubMed]

13. Raghavendra, S.S.; Jadhav, G.R.; Gathani, K.M.; Kotadia, P. Bioceramics in Endodontics-A Review. J. Istanb. Univ. Fac. Dent. 2017, 51, S128-S137. [CrossRef] [PubMed]

14. Jitaru, S.; Hodisan, I.; Timis, L.; Lucian, A.; Bud, M. The Use of Bioceramics in Endodontics-Literature Review. Med. Pharm. Rep. 2016, 89, 470-473. [CrossRef] [PubMed]

15. Kim, U.-S.; Shin, S.-J.; Chang, S.W.; Yoo, H.-M.; Oh, T.-S.; Park, D.S. In vitro evaluation of bacterial leakage resistance of an ultrasonically placed mineral trioxide aggregate orthograde apical plug in teeth with wide open apexes: A preliminary study. Oral Surg. Oral Med. Oral Pathol. Oral Radiol. Endodontol. 2009, 107, e52-e56. [CrossRef]

16. Aslan, T.; Esim, E.; Üstün, Y.; Özkan, H.D. Evaluation of Stress Distributions in Mandibular Molar Teeth with Different Iatrogenic Root Perforations Repaired with Biodentine or Mineral Trioxide Aggregate: A Finite Element Analysis Study. J. Endod. 2020. [CrossRef] 
17. Mir, S.; Gautam, A.; Batra, R.; Soni, S.; Lata, K. Evaluation of Antimicrobial Efficacy of Root Canal Sealers against Enterococcus faecalis: A Comparative Study. J. Contemp. Dent. Pract. 2018, 19, 680-683. [CrossRef]

18. Khalil, W.A.; Alghamdi, F.; Aljahdali, E. Strengthening effect of bioceramic cement when used to repair simulated internal resorption cavities in endodontically treated teeth. Dent. Med. Probl. 2020, 57, 165-169. [CrossRef] [PubMed]

19. Lim, M.; Jung, C.; Shin, D.-H.; Cho, Y.-B.; Song, M. Calcium silicate-based root canal sealers: A literature review. Restor. Dent. Endod. 2020, 45, e35. [CrossRef]

20. Zordan-Bronzel, C.L.; Torres, F.F.E.; Tanomaru-Filho, M.; Chávez-Andrade, G.M.; Bosso-Martelo, R.; Guerreiro-Tanomaru, J.M. Evaluation of Physicochemical Properties of a New Calcium Silicate-based Sealer, Bio-C Sealer. J. Endod. 2019, 45, 1248-1252. [CrossRef] [PubMed]

21. Chen, B.; Haapasalo, M.; Mobuchon, C.; Li, X.; Ma, J.; Shen, Y. Cytotoxicity and the Effect of Temperature on Physical Properties and Chemical Composition of a New Calcium Silicate-based Root Canal Sealer. J. Endod. 2020, 46, 531-538. [CrossRef]

22. Torres, F.F.E.; Zordan-Bronzel, C.L.; Guerreiro-Tanomaru, J.M.; Chávez-Andrade, G.M.; Pinto, J.C.; Tanomaru-Filho, M. Effect of immersion in distilled water or phosphate-buffered saline on the solubility, volumetric change and presence of voids within new calcium silicate-based root canal sealers. Int. Endod. J. 2020, 53, 385-391. [CrossRef]

23. Seo, D.-G.; Lee, D.; Kim, Y.-M.; Song, D.; Kim, S.-Y. Biocompatibility and Mineralization Activity of Three Calcium Silicate-Based Root Canal Sealers Compared to Conventional Resin-Based Sealer in Human Dental Pulp Stem Cells. Materials 2019, 12, 2482. [CrossRef] [PubMed]

24. Lee, J.K.; Kim, S.; Lee, S.; Kim, H.-C.; Kim, E. In Vitro Comparison of Biocompatibility of Calcium Silicate-Based Root Canal Sealers. Materials 2019, 12, 2411. [CrossRef]

25. López-García, S.; Myong-Hyun, B.; Lozano, A.; García-Bernal, D.; Forner, L.; Llena, C.; Guerrero-Gironés, J.; Murcia, L.; Rodríguez-Lozano, F.J. Cytocompatibility, bioactivity potential, and ion release of three premixed calcium silicate-based sealers. Clin. Oral Investig. 2020, 24, 1749-1759. [CrossRef]

26. Gaudin, A.; Tolar, M.; Peters, O.A. Cytokine Production and Cytotoxicity of Calcium Silicate-based Sealers in 2- and 3-dimensional Cell Culture Models. J. Endod. 2020, 46, 818-826. [CrossRef] [PubMed]

27. Sanz, J.L.; López-García, S.; Lozano, A.; Pecci-Lloret, M.P.; Llena, C.; Guerrero-Gironés, J.; Rodríguez-Lozano, F.J.; Forner, L. Microstructural composition, ion release, and bioactive potential of new premixed calcium silicate-based endodontic sealers indicated for warm vertical compaction technique. Clin. Oral Investig. 2020, 1-12. [CrossRef] [PubMed]

28. Rodríguez-Lozano, F.; Collado-González, M.; Tomás-Catalá, C.; García-Bernal, D.; López, S.; Oñate-Sánchez, R.; Moraleda, J.; Murcia, L. GuttaFlow Bioseal promotes spontaneous differentiation of human periodontal ligament stem cells into cementoblast-like cells. Dent. Mater. 2019, 35, 114-124. [CrossRef] [PubMed]

29. Silva, E.C.A.; Tanomaru-Filho, M.; Da Silva, G.F.; Delfino, M.M.; Cerri, P.S.; Guerreiro-Tanomaru, J.M. Biocompatibility and Bioactive Potential of New Calcium Silicate-based Endodontic Sealers: Bio-C Sealer and Sealer Plus BC. J. Endod. 2020. [CrossRef]

30. Kim, S.R.; Kwak, S.W.; Lee, J.-K.; Goo, H.-J.; Ha, J.-H.; Kim, H.-C. Efficacy and retrievability of root canal filling using calcium silicate-based and epoxy resin-based root canal sealers with matched obturation techniques. Aust. Endod. J. 2019, 45, 337-345. [CrossRef]

31. Milanovic, I.; Milovanovic, P.; Antonijevic, D.; Dzeletovic, B.; Djuric, M.; Miletic, V. Immediate and Long-Term Porosity of Calcium Silicate-Based Sealers. J. Endod. 2020, 46, 515-523. [CrossRef] [PubMed]

32. Kim, J.C.; Moe, M.M.K.; Kim, S.K. A micro-computed tomographic evaluation of root canal filling with a single gutta-percha cone and calcium silicate sealer. Restor. Dent. Endod. 2020, 45, e18. [CrossRef] [PubMed]

33. Versiani, M.; Rached-Junior, F.J.A.; Kishen, A.; Pécora, J.D.; Silva-Sousa, Y.T.C.; de Sousa-Neto, M.D. Zinc Oxide Nanoparticles Enhance Physicochemical Characteristics of Grossman Sealer. J. Endod. 2016, 42, 1804-1810. [CrossRef] [PubMed]

34. Jang, J.-H.; Lee, C.-O.; Kim, H.-J.; Kim, S.G.; Lee, S.-W.; Kim, S.-Y. Enhancing Effect of Elastinlike Polypeptide-based Matrix on the Physical Properties of Mineral Trioxide Aggregate. J. Endod. 2018, 44, 1702-1708. [CrossRef] [PubMed]

35. Siqueira, J.F.; Fraga, R.C.; Garcia, P.F. Evaluation of sealing ability, pH and flow rate of three calcium hydroxide-based sealers. Dent. Traumatol. 1995, 11, 225-228. [CrossRef] [PubMed] 
36. Viapiana, R.; Flumignan, D.L.; Guerreiro-Tanomaru, J.M.; Camilleri, J.; Tanomaru-Filho, M. Physicochemical and mechanical properties of zirconium oxide and niobium oxide modified Portland cement-based experimental endodontic sealers. Int. Endod. J. 2013, 47, 437-448. [CrossRef]

37. Al-Haddad, A.; Ab Aziz, Z.A.C. Bioceramic-Based Root Canal Sealers: A Review. Int. J. Biomater. 2016, 2016, 1-10. [CrossRef] [PubMed]

38. Vivan, R.R.; Ordinola-Zapata, R.; Bramante, C.M.; Bernardineli, N.; Garcia, R.B.; Duarte, M.A.H.; De Moraes, I.G. Evaluation of the radiopacity of some commercial and experimental root-end filling materials. Oral Surg. Oral Med. Oral Pathol. Oral Radiol. Endodontol. 2009, 108, e35-e38. [CrossRef]

39. Urban, K.; Neuhaus, J.; Donnermeyer, D.; Schäfer, E.; Dammaschke, T. Solubility and pH Value of 3 Different Root Canal Sealers: A Long-term Investigation. J. Endod. 2018, 44, 1736-1740. [CrossRef]

40. Dioguardi, M.; Di Gioia, G.; Gaetano, I.; Arena, C.; Caponio, V.C.A.; Russo, L.L.; Zhurakivska, K.; Adipietro, I.; Troiano, G.; Muzio, L.L. Inspection of the Microbiota in Endodontic Lesions. Dent. J. 2019, 7, 47. [CrossRef]

41. Dioguardi, M.; Di Gioia, G.; Illuzzi, G.; Laneve, E.; Cocco, A.; Troiano, G. Endodontic irrigants: Different methods to improve efficacy and related problems. Eur. J. Dent. 2018, 12, 459-466. [CrossRef]

42. Kwolek-Mirek, M.; Zadrag-Tecza, R. Comparison of methods used for assessing the viability and vitality of yeast cells. FEMS Yeast Res. 2014, 14, 1068-1079. [CrossRef]

43. Singh, A.V.; Kishore, V.; Santomauro, G.; Yasa, O.; Bill, J.; Sitti, M. Mechanical Coupling of Puller and Pusher Active Microswimmers Influences Motility. Langmuir 2020, 36, 5435-5443. [CrossRef]

44. Semun, S.; Kim, J.H.; Kim, N. Proinflammatory Cytokines Modulating Osteoclast Differentiation and Function. J. Rheum. Dis. 2016, 23, 148-153.

45. Langub, M.C.; Koszewski, N.J.; Turner, H.V.; Monier-Faugere, M.-C.; Geng, Z.; Malluche, H.H. Bone resorption and mRNA expression of IL-6 and IL-6 receptor in patients with renal osteodystrophy. Kidney Int. 1996, 50, 515-520. [CrossRef] [PubMed]

46. Mantovani, A.; Sica, A.; Sozzani, S.; Allavena, P.; Vecchi, A.; Locati, M. The chemokine system in diverse forms of macrophage activation and polarization. Trends Immunol. 2004, 25, 677-686. [CrossRef] [PubMed]

47. Ma, J.; Shen, Y.; Stojicic, S.; Haapasalo, M. Biocompatibility of Two Novel Root Repair Materials. J. Endod. 2011, 37, 793-798. [CrossRef]

48. D'Antò, V.; Di Caprio, M.P.; Ametrano, G.; Simeone, M.; Rengo, S.; Spagnuolo, G. Effect of Mineral Trioxide Aggregate on Mesenchymal Stem Cells. J. Endod. 2010, 36, 1839-1843. [CrossRef]

49. Singh, A.V. Top-Down versus Bottom-Up Nanoengineering Routes to Design Advanced Oropharmacological Products. Curr. Pharm. Des. 2016, 22, 1534-1545. [CrossRef]

50. Bruderer, M.; Richards, R.G.; Alini, M.; Stoddart, M.J. Role and regulation of RUNX2 in osteogenesis. Eur. Cells Mater. 2014, 28, 269-286. [CrossRef]

51. Eveline, P.; Yoshihara, K.; De Munck, J.; Cokic, S.; Pongprueksa, P.; Putzeys, E.; Pedano, M.; Chen, Z.; Van Landuyt, K.; Van Meerbeek, B. Modified tricalcium silicate cement formulations with added zirconium oxide. Clin. Oral Investig. 2017, 21, 895-905. [CrossRef]

52. Rajasekharan, S.; Vercruysse, C.; Martens, L.; Verbeeck, R. Effect of Exposed Surface Area, Volume and Environmental $\mathrm{pH}$ on the Calcium Ion Release of Three Commercially Available Tricalcium Silicate Based Dental Cements. Materials 2018, 11, 123. [CrossRef] [PubMed]

53. Waltimo, T.; Trope, M.; Haapasalo, M.; Ørstavik, D. Clinical Efficacy of Treatment Procedures in Endodontic Infection Control and One Year Follow-Up of Periapical Healing. J. Endod. 2005, 31, 863-866. [CrossRef] [PubMed]

54. Dabaj, P.; Kalender, A.; Eldeniz, A.U. Push-Out Bond Strength and SEM Evaluation in Roots Filled with Two Different Techniques Using New and Conventional Sealers. Materials 2018, 11, 1620. [CrossRef]

Publisher's Note: MDPI stays neutral with regard to jurisdictional claims in published maps and institutional affiliations. 